Photostat Price $\$ 1.80$

Microfilm Price $\$ 1.80$

Available from the

Office of Technical Services

Department of Commerce

Washington 25, D. C.

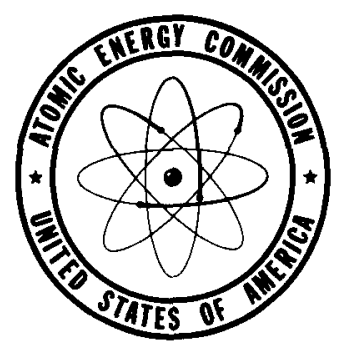

UNCLASSIFIED

\section{A URANIUM INHALATION EXPOSURE CASE HISTORY}

\section{Y-12 Plant}

Union Carbide Nuclear Company

Oak Ridge, Tennessee

Technical Information Service

\section{LEGAL NOTICE}

This report was prepared as an account of Government sponsorod work. Notther the Unitod Atates, nor the Commisslon, nor sny person acting on behalf of the Commisution

A. Makes any warranty or representation, expressed or Implied, with respect to the accuracy, completoness, or usefulness of the Information contalned in this report, or that the use pring lape

B. Asaumes any liabllities with respect to the use of, or for damagee resulting from the

of any Information, apparatus, method, or proceas disclomed in this report. ployee or conerector of the Comminaton, or omployee of euch contractor, to the axtent the such employee or contractor of the Commission, or employee of such contractor prepares. diszeminates, or provides sccess to, any Information puratant to bis employment or contract with the Commisslon, or his employment with such coatractor. 


\section{DISCLAIMER}

This report was prepared as an account of work sponsored by an agency of the United States Government. Neither the United States Government nor any agency Thereof, nor any of their employees, makes any warranty, express or implied, or assumes any legal liability or responsibility for the accuracy, completeness, or usefulness of any information, apparatus, product, or process disclosed, or represents that its use would not infringe privately owned rights. Reference herein to any specific commercial product, process, or service by trade name, trademark, manufacturer, or otherwise does not necessarily constitute or imply its endorsement, recommendation, or favoring by the United States Government or any agency thereof. The views and opinions of authors expressed herein do not necessarily state or reflect those of the United States Government or any agency thereof. 


\section{DISCLAIMER}

Portions of this document may be illegible in electronic image products. Images are produced from the best available original document. 


\section{A URANIUM INHAIATION EXPOSURE CASE HISTORY}

The regularly scheduled urine sample submitted in the routine urinalysis program provided the first indication that a machinist employed in facilities processing enriched uranium had inhaled significant quantities of uranium dust. When special request re-samples confirmed this indication, steps were taken to remove the person from further exposures to uranium-bearing atmosphere and to establish a program to permit the best evaluation of the exposure.

The person Involved in this case had been employed as a machine operator for about three and one-half months prior to his abnormal exposure. During the first ten weeks of his employment, he was working with normal rather than enriched uranium. Routine analyses during this period indicated a negligible Intake of uranium.

Routine analyses during the first four weeks of his work with enriched uranium indicated that he was excreting slight amounts of uranium, but not enough to require any special investigation or re-sample. The sample submitted on Monday morning after five weeks of work with enrlched uranium gave the first Indication of a high uranium intake.

The operator's job involved drilling small holes in uranium metal and then removing the burrs or sharp edges left by the drilling operation. These burrs were removed with the ald of several discs of emery cloth sandwiched together and mounted on a flexible shaft which was powered by a small pighspeed grinder motor. An eight-inch diameter flexible exhoust duct was supplied to control the uranium dust produced by the operation. This type of ventilation had proved adequate on similar operations in other shops. 
General air activity levels averaged $1.8 \times 10^{-12}$ microcuries per milliliter over the two weeks perlod involved, with no particularly high samples to indicate an unsatisfactory condition. The general air sampling data is not representative in the case at hand, since the table upon which the work was being done was quite close to one of the general ventilation exhausts from the room and some distance from the nearest general air sampling device. PostIncident investigation has ldentified the particulate as predominantly $\mathrm{U}_{3} \mathrm{O}_{8}$ with a size range of from 0.03 to 3.7 microns and a mass median diameter of 1.9 micron. The concentrations of uranium in air have been shown to vary by a factor as high as 150 , according to the care exercised and how judiciously the flexible ventilation duct was used.

Investigation has indicated that the exposure probably resulted from an operating technique in which the face was kept close to the work and the work was not kept in position for best utilization of the exhaust provided. This situation was made worse by the fact that, at some time during the period of concern, cleansing tissues were sucked Into the exhaust duct and lodged against a partially closed damper.

The employee was transferred from the uranium shop within one week of the initial indication of exposure. Evaluation of the body burden was undertaken utilizing the techniques of scintillation detection of uranium in vivo and analysis of body fluids (urine, feces, and blood). The type of work belng done and the material being handled precluded the likelihood that this was an intake of relatively soluble compounds of uranium. In-vivo counting bore out that there was a deposit of enriched uranium in the upper chest with no evidence of kidney loading. Analysis of fecal samples suggested almost negligible excretion of uranium via the gastrointestinal tract. Blood samples 
Indicated a low but relatively constant level of uranium in the blood stream (approximately 5 to 8 micrograms in total blood).

The in-vivo and urinalysis data indicate an initial lung burden of 3 to 5 milligrams of uranium which was being eliminated from the lung at a gradually decreasing rate. Initially, the effective half-Iffe for this elimination was approximately 20 days. It approached the 120-day theoretical effective halfIife some 130 days after the exposure ceased, and after approximately $70 \%$ of the uranium deposit had been eliminated. The first year cumulative radiation dose to the Iung from this deposit of uranium was estimated to be from 32 to 40 rem. This represents essentially the total expected radiation dose.

It is of interest to note that the net difference between the initial and the most recent in-vivo count indicates that over the 340-day span, 2.54 mg of uranium have been eliminated from the deposit in the upper chest, while over this same period a total of approximately $2.33 \mathrm{mg}$ has been detected in the urine. Figure 1 is a plot of the urinalysis and the in-vivo counting. A single curve was drawn through both sets of data, indicating the rate of excretion experienced.

Complete medical examination, X-rays and base-line functional studies indicate that the employee has suffered no deleterious effects from this exposure to uranium dusts. He has felt well and has had no complaints.

It is apparent that such exposures can occur without the conditions having been obvious even with a rather comprehensive air sampling program of both routine and special sampling. 


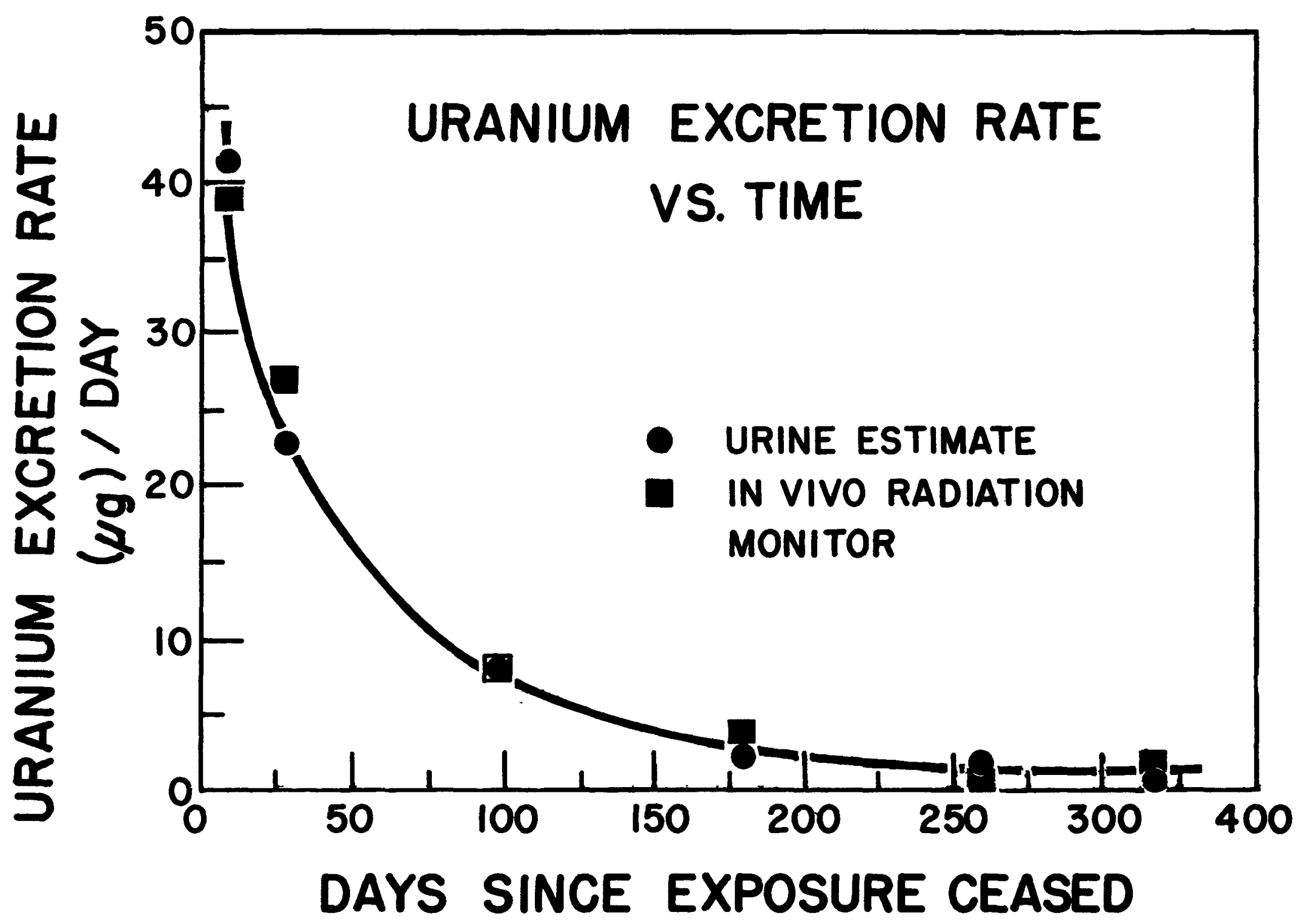

FIGURE I 